\title{
Climate Smart Agriculture and Climate Change
}

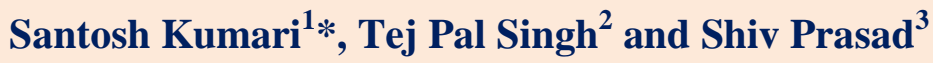 \\ ${ }^{1}$ Division of Plant Physiology, ${ }^{2}$ Seed Science and Technology, ${ }^{3}$ Centre for Environment \\ Science and Climate Resilient Agriculture, Indian Agricultural Research Institute, \\ Delhi, India 110012 \\ *Corresponding author
}

\section{Ke y w o r d s \\ Agricultural practices, \\ Biodiversity, \\ Carbon \\ sequestration, $\mathrm{CO}_{2}$ fertilization, GHG emissions, Resource management}

Article Info

Accepted:

10 February 2019

Available Online:

10 March 2019

\section{A B S T R A C T}

Agricultural practices and technological changes for agricultural production may allow 30$50 \%$ of land use for Afforestation that leads to the increased terrestrial stock of carbon. Carbon sequestration in forest soils decreases $\mathrm{CO}_{2}$ in the atmosphere and projected climate variability. $\mathrm{CO}_{2}$ fertilization effect and rise in temperature may affect plant growth and net primary productivity (NPP) by increasing soil respiration and increasing available nitrogen by mineralization. Global scenarios that need extra land to produce food, feed, and biomass energy generation result in low carbon storage. Building soil organic carbon (SOC) by multipurpose crops, woody perrenials, cover crops, effective crop rotations, minimum tillage and crop residue management is critical for supporting biological processes, nutrient availability and hydrological cycle. The conservation and precision agriculture saves fertilizer inputs, land, and water resources and reduces the emission of greenhouse gases (GHG). Agro-biodiversity offers a choice of diverse crops and ecosystem services, and options of different varieties reduce the risk of crop failure at farmers' fields. Crop species diversity and genetic diversity within species makes stable and productive agroecosystem that is less likely to harm by the variability of climatic factors, i.e., temperature, moisture, and photoperiod. $\mathrm{C}_{3}$ and $\mathrm{C}_{4}$ plants are grown at different times/seasons of the year and have different nitrogen requirement and root architecture (symbiont and non-symbiont). A legume provides biological nitrogen fixation, but phosphorous and potassium input would be required for maximization of yield potential. Diverse cropping systems conserve biodiversity, soil (SOC), water quality, and reduce fertilizer use thereby cut GHG emission. Family farmers have the knowledge of ecological and community requirements, past failure and consequences, therefore, their involvement in the technology-based agriculture help in finding realistic solutions for sustainable resource management.

\section{Introduction}

Climate-smart agriculture is comprised of agricultural practices that help farmers adapt to specific climatic factors especially temperature and rainfall. Several fields and farm-based sustainable agricultural operations like land management practices already in use are conservation tillage, agroforestry, residue management, crop shifting, intercropping, 
alley farming, multipurpose crops, water harvesting, drip irrigation for water and nutrient management depending on the availability of water, and irrigated and rain-fed lands. Improvement of these practices at local and regional levels in the context of a changing climate scenario would improve food security and livelihood opportunity. FAO's definition of climate smart agriculture emphasize management of forest lands, conservation of biodiversity, reduced inter sectoral competition for water (FAO, 2010). The World Bank (2011), version of climatesmart agriculture covers integrated planning of agriculture land with household needs and increased production from small land holdings, multipurpose water harvesting, climate resilience, and environmental sustainability.

The global vegetation follows the distribution of two climatic factors, i.e., temperature and rainfall. Therefore, climate variability will influence crop distribution, production and success at local, regional and global levels. Climate change and variability may result in severe consequences for cereal crops production by 2050 in developing countries. The food security of poor inhabitants in these areas is under stress and may worse progressively in the second half of the $21^{\text {st }}$ century in the lack of climate change mitigation via emissions of greenhouse gases. Land use change, crop production, and livestock production contribute 30,18, 12 and $14 \%$ of global GHG emissions.

Agricultural production will be reduced by climate-induced water scarcity from changes in time of rainfall, duration and distribution across the local, regional and global level (Antle and Capalbo, 2010; Fallon and Betts, 2010). Extreme weather events such as floods, fires and drought may increase GHG and further changes in climatic variability. Farmer's decision about agricultural inputs, land, crop, water, and labor management could influence the farm production and microclimates in the field.

Climate change will shift the geographical conditions of the production system and protected areas requiring new boundaries, zoning, and market shifting to new suppliers. Landscape planning involving farmer's decision at field level will facilitate such large-scale changes. Various initiatives of governments of different countries and Climate Change, Agriculture and Food Security project covering 21 countries in Asia, Africa, and Latin America, look to make agriculture sustainable and strengthen food, nutrition and health security with climate change.

\section{Landscape management}

Climate-smart landscape management includes sustainable use of natural resources such as water, grasslands, forest and ecological services (FAO, 2010; Scherr and Sthapit, 2009; Branca et al., 2011). Agricultural productivity is affected by differences in biophysical resources, management of field margins, and forest fragments that provide the habitat of pollinators adjacent to agricultural fields and stabilize pollination services (Harvey, 2007). Rainwater harvesting in forest improve living conditions for animals, birds, and insects and provide ecological connectivity. Expansion of grasslands, forest, and wetland provide local livelihood, tourism, and biodiversity conservation. These perennial systems absorb $\mathrm{CO}_{2}$, cut emissions, and increase soil $\mathrm{C}$ sequestration (Scherr and Sthapit, 2009).

Climate-smart agricultural landscape operates on the diversity of food crops with different dates of planting, various species of livestock, rainwater harvesting, and sustainable practices in the field. Climate change objectives need 
new approaches to sustainable agricultural growth that intensify ecosystem health and adaptability.

\section{Land use and agricultural management practices}

Agriculture lands cover about $38.5 \%$ of the global total land area, which consists of $28.4 \%$ arable land area and $68.4 \%$ permanent pasture and meadows (DSI MSU, 2015). Agriculture land use change is associated with two concepts: per unit profit and the opportunity cost of land. Profit refers to the willingness of farmers to manage the specific land use and will vary depending on biophysical characteristics of land, price, inputs, and access to markets and services. Opportunity costs include private production costs and ecosystem service costs. The opportunity cost concept compares the social and economic cost of different ways to use the same land area (Steinfeld et al., 2006).

Land degradation has been identified as one of the most important drivers of land conversion from forest land to croplands and pastures. The farmers exhaust their land resources and explore the more suitable area for cultivation. The expansion of pastures into marginal regions is limited. Therefore, areas with agroecological potential are brought under pasture lands (Asner et al., 2004). Forests sequester more carbon in soil and vegetation than croplands and pastures. Agricultural farmland sequesters $6 \%$ of global carbon while temperate, and pastureland tropical savannas collectively sequester 27\% (IPCC, 2000). However, soils sequester the most carbon in the terrestrial carbon cycle and double that of vegetation (Steinfeld et al., 2006). The soil carbon can be exhaust through the burning of crop residues, volatilization, and erosion of soil, agricultural land use change, and management practices (Bolin et al., 1982). When a forest is converted to farmland and pasture by burning or logging of biomass, high amounts of carbon are discharged into the atmosphere.

The significant technological changes, adoption, and mitigation by using improved farm practices may allow 30-50\% land use for afforestation (Boumer et al., 1998; Shvidenko et al., 2002). The terrestrial carbon (C) stock in temperate forests of US and Europe has been reported to be at higher level since 1950 (Delcourt and Harris, 1980; Kauppi et al.,. 1992; Heath et al., 2002) by land use change, agroforestry and forest management. Therefore, Carbon sequestration in forest soils decreases $\mathrm{CO}_{2}$ in the atmosphere and projected climate variability. Forest protection/ planting trees and enhancing forest area is well known for evapotranspiration cooling and lowering the minimum temperature at any site making local climatic condition relaxing for the diversity of plants and animals (Carnaval et al., 2009). $\mathrm{CO}_{2}$ fertilization effect and rise in temperature may affect plant growth and net primary productivity (NPP) by increasing soil respiration and increasing available nitrogen by mineralization. While, afforestation of reclaimed mine soil by establishing bioenergy plantation crops has been shown to sequester $\mathrm{C}$ through below ground stumps and large roots (Akala and Lal, 2000; Tolbert et al., 2000).

Latin America has converted the most land from forest to pasture and cropland, and livestock ranching is one of the drivers of this change (Wassenaar et al., 2007). Soybean expansion replaced 12 million hectares of rainforest (LEAD, 2014) in 2000-2005. GHG emission from various sources of livestock ranching viz; $9.2 \%$ from land use change, $6 \%$ due to pasture increase, and $3.2 \%$ is due to field crop expansion (Gerber et al., 2013). Land conversion from forest to pastureland may also reduce methane $\left(\mathrm{CH}_{4}\right)$ oxidation by 
soil microorganism, resulting in pastureland acting as net sources of $\mathrm{CH}_{4}$ when soil compaction from cattle hooves limit gas diffusion (Mosier et al., 2004). Studies suggest that pasturelands as a mitigation strategy can either increase or decrease GHG emission depending on the grazing management and history, climate and ecosystem (IFAD, 2010; Henderson et al., 2015). Grazing management that can increase $\mathrm{C}$ sequestration is: not exceeding pastureland carrying capacity by having an active stocking rate, rotational grazing and excluding degraded pastureland from livestock grazing (Tennigkeit and Wilkies, 2008).

\section{Animal production and GHG}

Usually, livestock respiration is not added as a net source of carbon dioxide (CO2) discharges because they are part of the global biological cycle. Under the Kyoto protocol (2005), the consumed amounts of $\mathrm{CO}_{2}$ in vegetative form are equivalent to those emitted by the livestock. Therefore, the animal is a carbon sink because a fraction of the carbon consumed becomes the live tissue of the animal and products such as milk. Livestock adds $4 \%$ of the world's anthropogenic $\mathrm{CH}_{4}$ releases through the enteric fermentation and management of manure (Gerber et al., 2013). Enteric fermentation evolved a $\mathrm{CH}_{4}$ byproduct through exhalation (Beauchemin et al., 2009) and considered as energy loss (Gerber et al., 2013).

Increasing the concentrate (high energy feeds containing cereal grains and oil meals) proportion in the animal diet can reduce methane emissions from the animal (Dourmad et al., 2008). Methane emissions vary depending on production systems and regional characteristics e. g. Climate and landscape (Gerber et al., 2013). Feed production contributes almost half of the GHG emission across livestock production process. India,
China, Brazil and United States are the countries that contribute the most methane emissions related to livestock production (IPCC, 2013). India, with the most significant livestock population in the world, emitted $11.8 \mathrm{Tg}$ of $\mathrm{CH}_{4}$ in 2003, 91\% derived from enteric fermentation (the most significant contributor in the animal production stage) and $9 \%$ from manure management (Chhabra et al., 2013). Feeding practices and manure management could moderate methane emissions (Thornton and Herrero, 2010). China has the highest global methane manurerelated emissions, primarily due to pig manure (Steinfeld et al., 2006). Liquid manure found in lagoons or holding tanks releases more methane than dry manure (Burke, 2001).

Livestock production will be influenced by heat stress and availability of water, especially in arid and semi-arid areas. Cattle produce milk and meat from grass and forage, and thereby make a significant contribution to food security, preservation of soil fertility and mitigation of climate changes. The industrialized agriculture of chicken and pork production has created massive environmental and social collateral damage. They mostly depend on imported soybeans grown as high input monoculture from South America, using land formerly under rainforests. The concentration of industrial production system in the US (Tyson) and Germany (PHW Group) dominate the world market and can have a devastating effect on local markets of developing countries.

Monoculture crop production reduces biological diversity, grassland, and conversion of forests and release of $\mathrm{CO}_{2}$, nitrous oxide emission from synthetic fertilizers, nitrification of soils and ammonia load in the atmosphere. Shifting to the diversification of livestock animals, crops and crop varieties, mixed crops, agroforestry and leaves of Zizyphus (ber), acacia and chickpea and 
integration of cattle production with agriculture had been the most promising adaptation measures under climate change.

\section{Cropping systems and $\mathrm{CO}_{2}$ fertilization effect}

Optimal management of the crops, water, and nitrogen supply will play a role in the realization of $\mathrm{CO}_{2}$ fertilization advantage. General circulation models (GCMs) projected towards precipitation declines during December to February in South Asia and Central America; precipitation falls in June to August in Central America, Southern Africa, and Brazil, and precipitation increases in December to February in East Africa. Therefore, diversity of crop species and land uses can reduce ecological risks due to climatic variability. High temperatures coinciding with critical growth phases, e.g., flowering and grain setting can lead to pollen sterility and dramatic yield reductions (Porter and Semenov, 2005) in both $\mathrm{C}_{3}$ and $\mathrm{C}_{4}$ crops. Mixed cropping with $\mathrm{C}_{3}$ and $\mathrm{C}_{4}$ species under environmental variability seem to be the most promising climate smart solution. Sunflower a $\mathrm{C}_{4}$ like a $\mathrm{C}_{3}$ plant (intermediate) offers a good choice for manipulation of biomass production with higher carbon contents, manipulation of root length by nitrogen management (Santosh Kumari, 2017) under climate change scenario. Sunflower seed oil is used for human consumption and biomass as feedstock for biofuel, maintain insects in the vicinity of the plant.

\section{Small landholders, subsistence agriculture and diversified livelihood}

These farmers exist on a continuum between crop intensification and subsistence production. Farm income and size of the land holdings vary with developing and developed nations. They go through low levels of technology, isolation, imperfect markets and unpredictable exposure to the world market (Chambers et al., 1989). Small landholders and subsistence producers and pastoralists often follow hunting or gathering of natural resources (off-farm) as well as crop production and livestock product (on-farm activities). Smallholders are subjected to diseases, livestock mortality, and forced to sell their produce, animals, and assets at lower prices, indebtedness, and out-migration. Social relationships within families and between households immensely influence the negotiations of production choices, knowledge management, and marketing (Fairhead and Leach, 2006). Fifty per cent of the rural population of the developing countries are small landholders ( 0.5 to 2.5 ha of cropland), and approximately $25 \%$ are landless. The proportion of smallholder in sub-Saharan Africa may be higher at 73\% (IFAD, 2011).

These communities are responsible for cultivating a vastly variable proportion of land across developing nations. They are responsible for growing $90 \%$ of rice, wheat, pearl millet and sorghum in India; additionally grow cocoa and cotton in Nigeria (Jazairy et al., 1992). The livelihood of smallholders and dryland farmers in India and Africa share specific features, such as biodiversity, integration of livestock into farming system, diversifying livelihood and efficient use of land, cash, labor without external inputs; are regarded as adaptive strategies to climate change.

These farmers may be involved in the synecoculture farm for on-farm conservation of old, local varieties and neglected/underutilized species and could promote the conservation, sustainable use, institutional and human capacity building of plant genetic resources for agriculture and climate resilience (Sthapit et al., 2010). Traditional breeding using wild perennials and phenotypic selection could be used to enhance 
photo insensitivity, drought tolerance, low nitrogen tolerance, adaptation to marginal land and climate change.

\section{Agricultural practices, water management and hydrology}

Water availability for a recommended number of irrigations for various crops is the critical factor for agricultural production. Agricultural production is also vulnerable to low, erratic, and excess rainfall. The soil structure, the water holding capacity of the soil, salinity/acidity, and quality of underground water are constraints in the crop production. The cropping intensity in the rainfed areas is affected by arid and semi-arid nature of climatic factors. The cropping intensity of drylands seldom exceeds 100 percent while under irrigation the cropping intensity reaches $140 \%$. Low water use efficiency of different crops is further affected by the limited use of improved seed, traditional crop systems, poor plant population, and inadequate measures of moisture and soil conservation. Temperature rise and intense radiations affect monsoon precipitation due to wind circulation from land to sea and vice versa. Changes in future hydrology and practices related to water management will affect adaptation programs. There are several uncertainties of climate impact on water and agriculture, multiple interactions between the two sectors.

However, growing flood hazards may present significant challenges for agriculture, and summer irrigation deficits may result from low winter rainfall and snowfall. Therefore, seasonal flows of river and water storage in the reservoirs fluctuate with climatic variations. The limited water supply and higher demands for irrigation enhance the vulnerability of agricultural production. Drought and flood uncertainties will further contribute to the need for robust management systems. Adaptations of advanced technologies in the water sector could provide additional advantages to farm production systems such as reduced flood risk and increased drought resilience.

Research efforts are required for the development of suitable cropping/farming system for rainfed limited irrigated, brackish water area. Development of techniques is urgent for efficient and safe use of good and brackish underground water for limited irrigations. However, excess rainfall of Kharif season over and above the usual water requirement of crops could be utilized by growing mixed/ inter-crops in the low water holding capacity of drylands. The method of seeding with ridge-seeder had proved useful in raising perfect plant population/stand and increasing crop yield in dryland farming. Winter crops could be possible to raise after summer fallow and effective conservation of rainfall. Straw mulching has proved the best method for moisture protection in loamy sand soils. Crops residue management improves soil organic matter (SOM), nutrient losses, surface runoffs and soil erosion, water holding capacity, need for irrigation, alter albedo, and emission of GHG (Post et al., 2000; Powlson et al., 2001; Falloon et al., 2004; Berndes et al., 2004; Huntington, 2006).

SOM status and soil moisture contents could also affect the radiative balance (Alexander, 1969; Fernandez et al., 1988; Schulze et al.,. 1993) that in turn affect evaporation from the soil and likely cause further regional cooling or warming. Since soil organic carbon (SOC) losses could enhance with rising temperatures (Jenkinson et al., 1991; Cox et al., 2000; Friedlingstein et al., 2006; Jones et al., 2005) and could change the status of soil nutrient, tilth, and water holding capacity.

Rises in sea level may lead to deterioration of farmland, especially in low-lying regions (IPCC, 2007) by torrent and escalate 
groundwater and soil salinity (Motha, 2007). Warmer winters and shorter snow seasons reduce the magnitude of the spring snowmelt peak and cold winds in February, March while extended cool season and humidity may delay mustard and wheat maturity and bring about production losses due to a hailstorm. Significant increases in irrigation, as well as drinking water demands, could occur particularly for central, eastern and western parts and both coastal regions of India as evident in recent past from water carrying trains, fight over river waters in south India and Maharashtra and Gujarat. These projections are not different from European regions (Bogataj and Susnik, 2007). The seasonality of river flow has also changed as obvious from flood trends. Groundwater is a significant segment of local water budget, and precipitation may affect surface runoff during the previous winter, and therefore, the local characteristics of catchments can assume importance. Groundwater recharge has increased by snowmelts and landslides in the Northern region of India particularly in valleys, i.e., Uttrakhand in recent past. Higher evapotranspiration and salinity could also dry out soils (Hulme et al., 2002; Bradley et al., 2005) especially during the summer. Competition for water withdrawal and water stress due to climate change is anticipated to increase by 2030. A secondary consequence of climate change could result in shifting of consumption patterns, and competition for water among domestic, industrial and agricultural uses might alter the freshwater availability for farm irrigation and other purposes.

Flooding also needs a cross-sectoral approach, e.g., urbanization increases the coverage of impermeable surfaces (IPCC, 2007b) by using agricultural catchments or water bodies and thus could amplify the risks of floods, e.g., Bangalore and Chennai flood in south India. Climate-smart agriculture or autonomous adaptations result from changes to meet altered demands, aims, and expectations. These actions are deliberately designed by the farmers at the local level to reduce the consequences of weather changes in field production. Deliberate policy decisions considering climate change and variability are required for planned adaptations (IPCC, 2008) and mitigations of damages to the agriculture sector including livestock.

Above average precipitation imply an overall excess; this could have direct adverse impacts including soil water-logging, enhanced insect and pests, anaerobic conditions and decreased plant growth (Bradley et al., 2005) or plant decay and death as evident in northern states of India, and result in shift from cotton to rice cultivation (Figure 3 and 3a). Total food grain production of India had increased since 1973 with an increase in the agricultural land expansion, irrigation expansion and per unit land production by cropping system reshuffling. Cotton production has declined mainly due to excess rainfall, waterlogged soils and consequently shifting to rice cultivation. Indirect impacts of excess water include agriculture operations being delayed or implemented when they could create compaction damage such as on wet soils, for instance, livestock treading (Webb et al., 2005; Montanarella, 2007). Decreased groundwater recharge could reduce water availability for irrigation and also lead to soil salinity, especially in marginal regions (FAO, 2003).

Soil erosion in drier soil conditions in arid areas is a real cause of land degradation, reduction in infiltration and water holding capacity and rising runoff (Stroosnijder, 2007). Drought occurrence, intensity, and duration of drought could increase yield variability, crop stress damage and crop failure (Jones et al., 2003; Chopra and Kumari, 1995; Santosh Kumari, 2010). 
However, these impacts could be offset by the beneficial effects of $\mathrm{CO}_{2}$ fertilization on water use efficiency of plants (Betts et al., 2007a) under climate change scenario. Droughts may reduce pasture productivity, irrigation potential, increase soil erosion and degradation via wind, livestock deaths (Gomez, 2005) due to low water availability for drinking, bathing, and cooling of animals shelters. Heatwave (2003) in Europe had significant impacts on farm production systems, reducing quality and quantity of farm products and grassland yields, especially in Central and Southern Europe (Bogataj and Susnik, 2007). Wildfire occurrences may also result in additional damages (Santos et al., 2002; Gomez, 2005). Drought may positively affect crops under certain conditions such as pest reduction, vicinity of crop roots to brackish water from the shallow water table, snow removal in snowy regions and lead to long-term water conservation and management practices.

\section{Energy Crops and Water Management}

Energy crops are evaluated by their high biomass production potential and its conversion into bioenergy. Sustainable use of natural resources must take into account the conservation of marginal and eroded agricultural lands and use of water resources for the production of bioenergy crops. Bioenergy production involves the cultivation, irrigation, fertilization, transportation of biomass to the bioenergy generation plants. Therefore, the biomass production potential and use of land and water resources in terms of cost for other food grain crops must offset the production cost and emission of $\mathrm{CO}_{2}$ and nitrous oxide and ammonia load on the environment.

In India, e.g., sorghum has been identified as the potential bioenergy crop. Traditionally, sorghum is cultivated for fodder, during rainy season across all regions of India. Being C4 plant sorghum has high water use efficiency. The crop is grown on all types of soil as a source of fodder for livestock integration into farming. The crop grows faster under variable temperature and humidity conditions of the rainy season. The $\mathrm{C}_{4}$ plants are the best suited to drought-prone areas of arid and semi-arid regions require minimum external inputs, short to medium duration, grow fast harvesting rainwater under warmer conditions. Similarly, in Europe, USA and, Brazil main biofuel crops are rapeseed, maize, and sugarcane, respectively, are grown under rainfed conditions, very little irrigation water is used for ethanol production. However, the diverse genetic structure of hybrids, landraces, and sorghum lines can be used for target environments to make them resilient (Doggett, 1988; House, 1985; Haussmann et al., 1998; Habyarimana et al., 2004b; Rattunde et al., 2013).

Traditionally, Indian farmers were following sorghum - mustard; cotton-wheat; pearl milletmustard; cotton - mustard/ chickpea, and sorghum - chickpea depending on the availability of water from monsoon rainfall. Sugarcane is grown under an excess of rainwater as well as to meet the domestic requirement of sugar and jaggery as a source of iron and all food preparations.

Research interventions are required to exploit the biomass potential of cotton and sugarcane for biofuel production and increasing soil organic matter. The biomass production potential can be manipulated by using plant growth regulators, changing crop macro and micro-nutrient requirements and biomass partitioning as well as reducing recalcitrance nature of biomass (Santosh Kumari unpublished work). Different grasses elephant grass, tall fescue, etc., perennial hardwood species used for paper products which reduce soil erosion and act as a fence, are promising 
bioenergy crops. These crops have vast adaptability and excellent disease resistance (Lemus and Lal, 2005).

\section{Cereal shifts/ green revolution and crop intensification}

The focus of green revolution on high yielding varieties and considerable input responsive crops such as rice and wheat resulted in policies favoring their cultivations. The easy cooking, different taste, and soft food made these cereals the preferred choice of the people especially old persons and children. Further, these crops received research, extension and market support. Favorable policies for the cultivation of soybean, sunflower and cash crop such as cotton became productive and more profitable due to increased consumers demand, high prices and high yield. A technology mission of government to promote the cultivation of oilseeds and pulses further reduced the farmer's interest in cultivating coarse cereals. The cereals remain fit for human consumption for a short storage period in rural setup, dampened their cultivation.

Diversion of sorghum cultivated areas to crops such as sunflower, maize, groundnut, sugarcane, cotton, onion due to the availability of irrigation and higher prices reduced area under coarse cereals. Overall Rabi sorghum production increased by $83 \%$ from 1971 to 2009 while Kharif sorghum production declined by $52 \%$. The production of Kharif sorghum increased till 1990 due to the use of hybrids and improved cultivars despite a sharp decline in the area. Currently, 55\% of the area is under rabi sorghum compared to $35 \%$ in the 1970s. Pearl millet area and production increased till the 1970s and declined during 1980s due to downy mildew epidemics. The epidemic has remained the most critical factor in rejecting the pearl millet in Haryana. The Kharif sorghum in north India is used only for green and dry fodder for later storage, while Rabi sorghum is for human consumption in central and south India.

The economic contribution of sorghum to the total income is $50 \%$ in varieties and $40 \%$ in hybrids in Maharashtra, Andhra Pradesh and Haryana as fodder for livestock which is a complementary activity that provides stable income. Pearl millet plays a crucial and vital role in maintaining ecological security. The breeding efforts are needed for drought (Santosh Kumari, 2017; 2017a) and heat tolerance, and resistance to diseases such as downy mildew, smut, rusts.

Post-harvest processing of coarse cereals millets is still in infancy, with no policy provision, lack of advanced storage facilities and support at the farm level. The price disadvantage of farmers from rain-fed regions due to the shortage of storage facilities and bargaining capacity is exploited by middlemen, who garner the product during peak arrival at harvest season and store the grain to reap the time utility.

Further, improving the nutritional quality of fodder and grain quality improvement by increased starch contents, reduced phenol content to increase the shelf life of pearl millet and use in alcohol industry are essential areas of research. De-husking of grains before food processing causes respiratory problems which need developing small-scale machinery for slight moistening, beating, spinning and then removing straw and grain cover to help avoid women drudgery. Sorghum and pearl millet can substantially contribute to food, nutrition and financial security of small, marginal farmers. Coarse grains of both the crops are the most abundant source of iron, calcium, and zinc among cereals. Mixing of wheat/rice/chickpea flour with coarse grains is the most popular strategy in food processing for the nutritional security of growing 
population. The crop stover is used for fodder of livestock.

\section{Crop Residue Management for Soil Carbon Conservation and Sequestration}

Soil productivity has been found to be increased with increase in soil organic carbon (SOC) by practicing direct seeding in combination with the sustainable management of crop residues ( Lal, 2005). The increase in SOC improves the physical structure of the soil and soil chemical characteristics that enhances nutrient supply to the plants. Green plant fix carbon dioxide into simple sugars and complex hemicellulose, cellulose, and lignin. Carbon is cycled through the biosphere and reaches the soil in the form of dead plants, root exudates, dead animals, etc. and decomposed by soil microbes and respired back into the atmosphere as $\mathrm{CO}_{2}$.

The soil is the third bigest carbon pool on earth. Building SOC by cover crops, minimum tillage, and crop residue management is critical for enhancing biological processes and plant nutrient availability and hydrological cycling. Indian economy depends upon wheat, rice, cotton, sugarcane, and oilseed crop mustard. Well developed roots of cotton plants and leaves increase soil carbon; woody biomass is used as fuel for cooking and heating water for domestic purposes, cotton for filling quilts and cycled next year for making bed sheets used in summer for cooling effect. The crop provides ground cover, retain organic matter and water in the soil for next crop post rainy season. Similarly, mustard is grown as an intercrop, sole crop, field margins managements to control soil erosion, and addition of organic matter and nutrients to the soil. Further work is required on an understanding of how management of cotton or perennial versus annual using fertilizer/ plant growth regulators may affect soil C sequestration.

\section{Effective crop rotations}

Crop rotation is a profitable way of growing a sufficient amount of food at the inexpensive environmental cost. The criteria for crop species selection should be based on the optimization of soil resources use that is the usual limiting factor for crop production. Crop rotation methods can result in improved soil organic carbon content by long crop cover periods, decreased number and tillage intensity. Advancement in the use of forages in crop rotation scan occurs in better crop residue management while higher soil organic carbon content assists to combat climate change. The increased yields of sorghum were attributed to the higher levels of nitrogen made available in the soil by the $\mathrm{N}$-fixing legume (80- $135 \mathrm{~kg} \mathrm{~N}$ ha $^{-1)}$ or by the reduced $\mathrm{N}$ removal by sunflower from the soil (Varvel and Wilhelm, 2003; Kaye et al., 2007) in rotation. Sunflower can also be grown as an indicator of nitrogen in the soil (Santosh Kumari, 2017). Crop rotation management and precise amount of fertilizer application reduce residual soil nitrate and nitrous oxide emissions. Biological nitrogen fixation can be influenced by farmers via inoculation of legumes with nitrogen-fixing and phosphorous solubilizing Rhizobia (Santosh Kumari, 2017). In agricultural ecosystems, about 80 percent of biological nitrogen fixation is achieved through the symbiotic association between legumes and the soil bacteria (Rhizobia). Symbiotic nitrogen nutrition enlarges root system into deeper soils, and such roots are less susceptible to oxidation of organic matter and add $\mathrm{C}$ to the soils.

Bagayoko et al., (2000) revealed that substantial infection by arbuscular mycorrhizae of sorghum roots grown in rotation with legumes contributed in significantly higher yields. The energy crop hemp could be raised as nematicide when rotated with susceptible crops, i.e., cereals, 
potatoes, maize, peas, and pastures (Kok et al., 1994). Liquid manure induces a priming effect on soil organic matter and increases $\mathrm{CO}_{2}$ emissions. In contrast, when crop residues on the surface of field soil did not decay affect new crop establishment, may result in fungal infection in the new seedling.

The decomposition of old rooting systems adds organic matter at greater depths. When conditions are uncertain for agricultural production system versus opting new system or retaining the option to switch later on is driven by domestic and social needs of farmers in general. Research interventions to develop integrated pest-nutrient management cropping systems can help farmers mitigate, adapt and manage climatic risks.

\section{Conservation agriculture}

Minimum soil tillage increases the populations of earthworms, millipedes, mites and other animals living in the soil. These micro fauna takes over the task of tillage and builds soil porosity and improves soils structure. Conservation agriculture reduces water loss in post rainy season crops, reduces soil erosion in arid and semiarid areas and restore degraded soils. No-tillage practice reduces the number of farm operations and saves fuel and energy (Lal, 2005). Reduced farm operations and machinery manufacturing lead to cut emissions.

\section{Precision farming}

Precision farming equipment makes it possible to match water and nutrients inputs with plant requirements and improves water and fertilizer use efficiency (Santosh Kumari, 2011) as well as cutting direct and indirect greenhouse gas emissions. Drones, cameras, water sensors and computers are available for specific interventions in irrigation and nutrient management.
Wind and solar energy powered agricultural machinery can reduce emissions, complicated logistics and construction of substantial infrastructures required to supply fossil fuels in the rural areas. Sustainable mechanization can create opportunities to provide hired services for field operations, improve transportation and agro-processing, and increase the possibilities for adding value to farm production, efficient use of resources.

\section{Degradation of natural resources and farming systems}

Climatic change may result in severe loss of arable land and water resources; regional and local consequences for crop production. These losses will be felt immensely in developing countries. The Great Green Wall Initiative adopted in 2006 by African Union is a response to the degradation of resources exploited by growing population pressure. The drought has further affected the rural livelihood and environment. A farmer who survives on land has many social, health, and economic objectives including consumption and lifestyle. With extreme adverse conditions, the farmer, i.e., a cotton grower might switch to rice growing regime and sugarcane grower can switch to sorghum or pearl millet (Figure 1). However, the shifting of crops is always subjected to risks and crop losses due to uncertainties of climate variability. The progressive and educated farmers in the communities/villages play an essential role in such decisions.

1. Soil salinity and high water table affected sugar cane grown in rainy season in semi-arid areas (Bhiwani) of Haryana, India

2. Salt-affected rice fields and crust formation on soil

3. Protected cultivation of vegetables (cucumber, capsicum, and tomatoes) in the same region as cash crops

4. Rice field-rain fed crop 
Madagascar's rice producing area has been identified as a priority for adaptation to climate variability and excessive weather proceedings. A dense population and high level of poverty, poor arable lands, hampered economic development due to political instability, had reduced adaptive capacity and food security of the island's inhabitants (UNEP, 2011).

Recent developments in geographical information systems and database modeling provide the mitigation strategies and adoption of smart agriculture. Globalization, multinational companies, socioeconomic developments, economic growth would significantly, and climate change will additionally modify agricultural activities.

The technological characteristics adopted in agriculture, all industries, household activities will have to cut emissions to reduce the extent and pace of climate change.

Africa and India have been projected to be the most adversely impacted developing countries under climate change scenario; and by 2080 . The regional and local scenarios are complicated due to food habits, land size, drought or flood, socio-economic status, livestock production.

Therefore, different farming systems play an essential role in sustainable livelihood and economic development in addition to the adaptation/mitigation of climate change variables. The farmers time the growth of the crop to coincide with the maximum available water. Farmers in these areas often plant two crops: one that will yield some food if rains fail, and other will yield abundantly with timely rains. Farmers grow sole crops, diverse species of the same crop, mix crops and intercrop for food, forage, and fodders in salinity affected fields in Delhi -NCR of India (Figure 2).

\section{Alley farming}

Alley farming as an alternative to slash and burn adopted by African farmers involves cultivating food crops between multipurpose trees and shrubs (leguminous trees and shrubs). The farmers plant tree and shrubs in rows and food crops in the 'alleys' between rows. Legumes have deep roots that help draw up soil nutrients from deeper soil layers and harbor symbiotic nitrogen-fixing bacteria in their nodules. Farmers can use the nitrogenrich leaves of the trees as fertilizer, mulch or fodder for livestock. The villages characterized by high land use pressure, the decline in soil fertility, soil erosion problems and firewood, and animal fodder scarcity. The survey conducted in Nigeria, Benin, and Cameroon show that farmers have modified the alley farming by planting fruit and commercial trees, e.g., banana, coffee, and cocoa and by including fallow periods. High labor demands, lack of knowledge about management and scarcity of stocks of hedgerow legume trees and shrubs are the factors those hindered the widespread adoption of this farming system.

\section{Cover crops}

Excessive rainfall, prolonged flooding, and erosion can remove topsoil, nutrients, organic matter and microbes. Growing a cover crop during all time of the year is a crucial concept for improving water and nutrient cycling, soil health, soil protection and building organic matter. Cover crop help builds up soil aggregates on the surface, reduce ponding by increasing water infiltration and break through compaction layers in deeper in the soil. Some cover crops such as cereal rye can help suppress certain weed, i.e., marestail along with forage harvest system. Cover crops can be designed to use a high amount of soil moisture to dry up soil for next planting. Earthworm and insects associated with the 
chosen crop are an excellent food source for birds. In a corn-soybean rotation, soybean followed by cereal rye cover crop is a favorite option for the no-tillage practice of Prairie farmers. The successive fallow system adopted by Rwanda farmers is also adopted in India (Haryana) following two years of cropping and one fallow year. Farmers have obtained significant yield increases and fodder for livestock by growing leguminous crops like rijka (Trigonella sps), methi (Medicago falcata), and Bersin (Trifolium alexandrinum). These cover crops establish easily and rapidly, develop a dense cover, therefore, suppress weeds. These crops are drought tolerant and regenerate rapidly when cut for forage. In West and Central Africa, fallow based on velvet beans (Mucuna pruriens) have become popular, this legume can restore soil fertility, reduce insect pests, and smother spear grass, the noxious weed that leaves severely poor soils. These legume crops cover the ground and act as live mulch.

\section{Climate-resilient crop intensification}

In developing countries, climate change will cause a decline in yield of most crops, and $50 \%$ reduction in wheat and rice production has been projected in AEZ and GCMs. In India, public food policy is based entirely on these cereals; therefore, survival from the crisis needs to fall back on the crops those are minimally affected by excess or deficit of water. Strengthening of coarse grain cereals production especially pearl millet based dryland farming system is one way of minimizing the malnutrition and climate change adaptation. Pearl millet and chickpea is grown on marginal lands from zeroinvestment agriculture, resistant to drought, ensure nutritional, health, food and fodder security, creates a livelihood for the community. This will precisely be the disaster preparedness for farming. India has been more vulnerable to floods, drought, cyclones, earthquakes, and landslides on account of its unique geo-climatic conditions. Approximately $60 \%$ of the landmass is prone to earthquakes of multiple intensities. Over 40 million hectares land is likely to floods. About $8 \%$ of the total area of the country is prone to cyclones, and $68 \%$ area is sensitive to drought. Inadequate risk mitigation support and near absence of opportunities for non-farm employment with recurrent natural disasters make farmer's lives complicated and challenging. Severe drought and floods may destroy livestock, feed and fodder crops, forest lands, and water resources. New ecological initiatives such as biofertilizers and biopesticides production at household as well as community levels, build new strengths for people's existing capacity to create a more resilient future.

More than $90 \%$ of the world rice is grown in continuously flooded paddies, I $\mathrm{kg}$ of rice production uses 2,500 liters of water which result to water productivity of $0.4 \mathrm{~kg}$ per cubic meter (Bouman et al., 2007). The aerobic rice (local multicolored basmati varieties) production system earlier used in wheat growing region of India (Haryana) need less water and targeted at limited irrigation or rainfed lowland environments is an example of climate resilient agriculture. Irrigation can be given by flash flooding, furrow irrigation, alternate wetting and drying irrigation with other options of no-tillage in combination with mulch, raised beds, land leveling. This production system reduces fuel for pumping water, reduces overall methane emission due to anaerobic conditions by flooding. The rice under this system matures earlier, and the land becomes available for the timely sowing of the next crop and reduces the risk due to snakes.

Species diversity is essential to sustain the yield potential with the changing environmental factors such as temperature, humidity, and soil moisture availability. Data 
obtained for wheat cultivars (Table 1 and 2) in field trials conducted with 105 wheat Accessions at National Burro of Plant Genetic Resources (NBPGR) in the year 2010-11 \& 2011-12 agree with the feasibility of changes in dates of sowing with climatic variability. Predicted drought and temperature/heat stress can be avoided by shifting the date of crop sowing. The final outcome of drought due to high temperature and radiation under late sown conditions is reduced internodes length; plant height, leaf area, biomass and duration of developmental phases altogether result in lower wheat yields (Santosh Kumari, 2010).

A diverse crop portfolio is advantageous in switching off to an alternative climate scenario. Effective agricultural insurance is a safety net that can act as a desirable cushion in the event of disasters. Insurance has to be comprehensive linking production risks of inputs and weather as well as market risks. Government expenditures should be focused on productive sectors, i.e., irrigation, infrastructure, and power (biofuels) that can benefit farmers to build the resilience of farmers.

\section{Sustainable livelihood}

Successful implementation of sustainable livelihood (SL) needs significant differences in the roles traditionally played by researchers and crop growers. The experts can support to catalyze farmers' empowerment by serving as conveners of farmers' meetings; expediting the information of technological options, machinery, seeds, planting decisions, integrated pest management, soil conservation, systematic utilization of traditional knowledge to mitigate the challenges of climate (Chambers, 1991).

Emphasis must be placed on technologies that overcome risk (e.g., new more resistant/ tolerant crop species and agronomic practices that reduce the impact of biotic and abiotic stresses, technologies that support enterprise diversification). The Mizoram (India) legislative assembly passed the organic farming bill in July-2004. Organic farming coupled with contour trench farming was trialed at Lungmuat in 1996 with promising results. Now the state agriculture department has 10 model organic farms. Demonstrations have been conducted on effective microorganisms, bio-dynamics, vermicompost and other biofertilizers on farmers' field and model farms on sugarcane, popcorn, cowpea, maize, paddy, turmeric, vegetables, and fruits. Cert Asia Agriculture certification (P) Ltd is engaged in group certification for the internal control system of organic products of various farmers groups. Crop residue, organic manure, biofertilizers, biological pest control are used for sustainable soil fertility and reduce the import of agriculture chemicals i.e., fertilizers and pesticides (Agriculture Department of Mizoram).

\section{Biodiversity}

The living organisms respond to the environmental cue by adaptation, avoidance and survival strategy. The organisms maintain their body temperature by heating, cooling, hibernation, migration, covering the body parts, growing hair, changing pigments and color of hair, skin, leaf color and shape, flower color, etc. Therefore, optimum environmental temperature requirement for various crops and organisms is variable. The multiple components of climate change such as temperature, $\mathrm{CO}_{2}$ concentration, humidity, heat waves, and water abundance are anticipated to affect biodiversity from organism to biome levels. Climate variability may change the duration of vegetative/ reproductive stage/ flowering stage in plants and availability of sufficient population of insect pollinators; thereby mismatch may result in the extinction of both (Kiers et al., 
2010; Rafferty and Ives, 2010). One of the critical questions on the impacts of climate change is whether or not species will be capable of adapting fast enough to keep up with the quick pace of changing climate. Adaptation to new climatic conditions through expression of conserved evolutionary traits or selection of existing genotypes based on morpho-physiological characters or plasticity within individual genotype's lifecycle provide smart solutions (Charmantier et al., 2008; Visser, 2008; Salamin et al., 2010; Chevin et al., 2010; Hoffman and Sgro, 2011; Santosh Kumari, 2010; 2013). Flowering, fruiting and seasonal migrations time shift has been reported in response to climatic factors, i.e., temperature and rainfall (Parmesan, 2006; Santosh Kumari, 2010). Species can survive by morphological, physiological and chemical alterations that permit tolerance to warmer and drier conditions (Santosh Kumari, 2010) accompanied with yield penalties by differences in heat degree days (developmental durations) under changing climatic conditions. Agricultural resource management strategies and alleviation of global warming could, therefore, have profound impact on the safeguarding of species from disappearance (Hansen et al., 2010).

Improved upland rice varieties have been developed by an interspecies cross between Asia rice (Oryza sativa) and African rice (Oryza glaberimma). Target traits include resistance against rice yellow mottle virus, rice blast, African rice gall midge, adaptation to fluctuating water tables, competition with weeds, and drought resistance. Biodiversitybased adaptation strategies (blending traditional coping methods, i.e., indigenous crop varieties and livestock species, tools, methods, and approaches) are critical in countering situations of climate change. Random inconstancies in agricultural output caused by weather or additional factors will be inversely related to prices and gross revenue, is a well-documented aspect. In India, about 70 million hectares cultivable land is under rainfed agriculture, spread over parts of Haryana, Rajasthan, Madhya Pradesh, Uttar Pradesh, Maharashtra, Karnataka, Andhra Pradesh, and Tamil Nadu. Integrated rainwater harvesting and drainage system strategy offers a smart solution to manage soil and crop more efficiently for sustainable production. The development of sorghum, pearl millet, maize, cassava and dual-purpose grain legume (cowpea) varieties that do well in the marginal areas should be the top priority for climate change. The adoption of resource conservation practices in agriculture is a pressing need to cope with growing population pressure on crop production, under eroding environment and uncertainties from climate change. Sustainable crop production intensification offers the opportunities for optimizing agricultural crop productivity per unit area, considering the series of sustainability aspects including potential and existing social, political, environmental and economic issues. Mitigation of GHG emission, adaptation science, and implementation will be defining human endeavors for the rest of the twentyfirst century.

\section{Future areas of research}

Pearl millet, sorghum, and groundnut are critical for nutrition and food security in Sahelian areas of West Africa as well as dry and semi-arid regions of India where soil fertility and climatic factors drought, temperature, heat and low water availability may turn agriculture into an unsustainable livelihood. Therefore, research efforts are required for identification of traits useful for breeding genotypes with improved adaptation, and production to climate variability. Agrobiodiversity offers a choice of diverse crops and options of diverse varieties reduces the risk of crop failure at farmers' fields and 
provides a solution for smart climate agriculture. Different dates of sowings, early sowing, tolerance to low /or high temperature during germination and seedling establishment, shortening and extending the period of phenological stages, delayed senescence and stay green characters, tolerance to salinity, and submergence of rice and cotton, sudden water stress can be managed using agro-biodiversity.

It is more promising to manipulate the infection potential of the indigenous vesiculararbuscular mycorrhizae (VAM) and microorganisms by soil management and crop rotation. The selection of genotypes resistant to root pathogens infection might also involve risk of simultaneous resistance against VAM infection.

The landscape/ forest management practice should aim at diverse tree species to increase soil microorganisms, especially in tropics. These efforts deserve more attention for ecological reasons in low and high input production systems. Manipulation of diverse farming systems and crop management via crop rotation, intercropping, mix crops, cover crops, crop residue management help improving soil health, organic matter, nutrient cycling and saving and sequestering carbon in soil under climatic variability in different regions. Further research efforts are required on testing and integrating these aspects with water, field, and crop management practices for different sizes of land holdings.

Climate is changing and will continue to change with growing concerns of food and nutrition security. Crop production in agroecosystem relies on the processes like nutrient recycling, predator-prey relationship, competition and succession that maintain and enhance natural ecosystem. Modifications of agro-ecosystem to increase production with fewer inputs lead to sustainable resource management with fewer negative environmental consequences to achieve sustainable development.

Changes in land management, land use, restoration of degraded lands, afforestation, reducing deforestation, efficient fertilizer and crop management integrated with livestock production, improved feed systems, and manure management can significantly cut GHG emission.

Agro-biodiversity offers a choice of diverse crops and options of diverse varieties reduces the risk of crop failure at farmers' fields and provides a solution for smart climate agriculture.

Post rainy season soil moisture availability can be manipulated by changing the date of crop sowing and agronomic practices to shorten or enhance the genotype growth duration for maximization of yield.

Different dates of sowings, early sowing, tolerance to low /or high temperature during germination and seedling establishment, shortening and extending the period of phenological stages, delayed senescence and stay green characters, tolerance to salinity, and submergence of rice and cotton, sudden water stress can be managed using agro-biodiversity. Research interventions in integrated pestnutrient management cropping systems can help farmers mitigate, adapt and manage climatic risks.

Livestock production is the only way to sustain families of the marginal and small landholders. Livestock production should be integrated with the cropping system for feed base and crop production for fossil fuel energy saving to cut GHG. 
Table.1 Percent reduction in morphological and agronomic traits of wheat cultivars under terminal heat stress condition (late sown) over the years (2010-11-2012)

\begin{tabular}{|l|l|l|l|l|l|l|}
\hline $\begin{array}{l}\text { Accession ID } \\
\text { Cultivar }\end{array}$ & $\begin{array}{l}\text { IC75240 } \\
(\text { C-306) }\end{array}$ & $\begin{array}{l}\text { IC75226 } \\
\text { (WG377) }\end{array}$ & $\begin{array}{l}\text { (IC75215) } \\
\text { PBW34 }\end{array}$ & $\begin{array}{l}\text { IC252632 } \\
(\text { HD2687) }\end{array}$ & $\begin{array}{l}\text { IC-303070 } \\
(\text { HD2781) }\end{array}$ & $\begin{array}{l}\text { IC-75191 } \\
\text { (DL1532) }\end{array}$ \\
\hline Traits & Percent reduction & \multicolumn{1}{|l|}{} & & & \\
\hline DSE & 10 & 7.1 & 11.68 & 9.28 & 11.83 & 12.17 \\
\hline DPM & 12.83 & 14.65 & 14.64 & 10.7 & 12.22 & 14.03 \\
\hline PH & 6.6 & -3.65 & 8.65 & 2.34 & 1.08 & -1.68 \\
\hline BYP & 15.74 & 17.87 & 9.19 & 20.84 & 17.35 & 29.05 \\
\hline TP & 25.37 & 34.48 & 5.56 & 4.35 & 8.33 & 22.22 \\
\hline SL & 8.66 & 9.71 & 10.66 & 7.66 & 9.81 & 5.68 \\
\hline GS & 2.49 & 11.04 & -3.23 & 6.8 & 3.33 & -5.38 \\
\hline GYP & 10.09 & 22.62 & 8.06 & 17.4 & 17.99 & 16.76 \\
\hline TGW & 26.4 & 9.93 & 21.11 & 35.96 & 30.5 & 50 \\
\hline HI & -7.12 & 6.39 & -1.14 & 11.09 & 0.73 & -16.45 \\
\hline
\end{tabular}

Table. 2 Pearson correlation of grain yield and morphological and agronomic traits of wheat cultivars under normal (below diagonal) and late sown conditions (above diagonal)

\begin{tabular}{|l|l|l|l|l|l|l|l|l|l|l|}
\hline & DSE & DPM & PH & BYP & TP & SL & GS & GYP & TGW & HI \\
\hline DSE & 1 & $0.67^{* *}$ & 0.18 & $0.30^{* *}$ & $0.26^{* *}$ & -0.01 & $0.32^{* *}$ & $0.37^{* *}$ & 0.09 & $0.25^{*}$ \\
\hline DPM & $0.59^{* *}$ & 1 & $0.31^{* *}$ & $0.27^{* *}$ & $0.38^{* *}$ & 0.04 & $0.38^{* *}$ & $0.33^{* *}$ & 0.08 & $0.21^{*}$ \\
\hline PH & -0.02 & 0.10 & 1 & $0.26^{* *}$ & $0.24^{*}$ & -0.16 & -0.02 & 0.19 & 0.06 & -0.03 \\
\hline BYP & $0.39^{* *}$ & $0.43^{* *}$ & 0.05 & 1 & $0.54^{* *}$ & 0.00 & $0.36^{* *}$ & $0.89^{* *}$ & $0.34^{* *}$ & 0.10 \\
\hline TP & $0.32^{* *}$ & $0.38^{* *}$ & -0.05 & $0.66^{* *}$ & 1 & 0.04 & $0.20^{*}$ & $0.48^{* *}$ & 0.17 & 0.08 \\
\hline SL & $0.21^{*}$ & 0.09 & -0.14 & 0.17 & 0.08 & 1 & $0.43^{* *}$ & -0.02 & -0.10 & -0.06 \\
\hline GS & $0.31^{* *}$ & 0.18 & -0.10 & $0.31^{* *}$ & 0.07 & $0.41^{* *}$ & 1 & $0.41^{* *}$ & -0.05 & $0.24^{*}$ \\
\hline GYP & $0.36^{* *}$ & $0.35^{* *}$ & 0.00 & $0.91 * *$ & $0.56^{* *}$ & 0.07 & $0.29 * *$ & 1 & $0.37 * *$ & $0.53^{* *}$ \\
\hline TGW & -0.25 & -0.11 & 0.11 & -0.23 & -0.24 & -0.35 & -0.29 & -0.14 & 1 & 0.19 \\
\hline HI & 0.00 & -0.06 & -0.10 & 0.05 & -0.06 & -0.19 & 0.04 & $0.44^{* *}$ & $0.20^{*}$ & 1 \\
\hline
\end{tabular}

Fig.1 Degradation of natural resources and farming systems

1

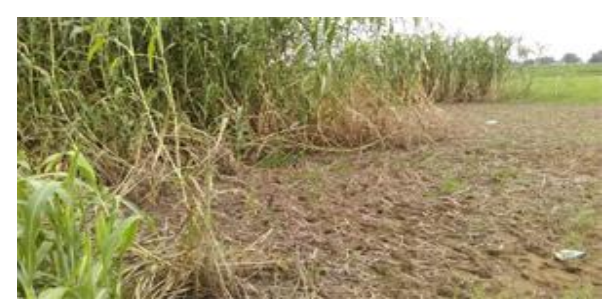

3

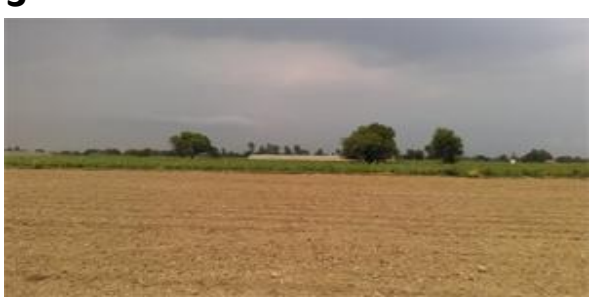

2

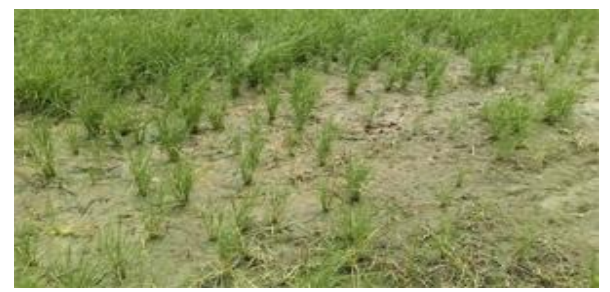

4

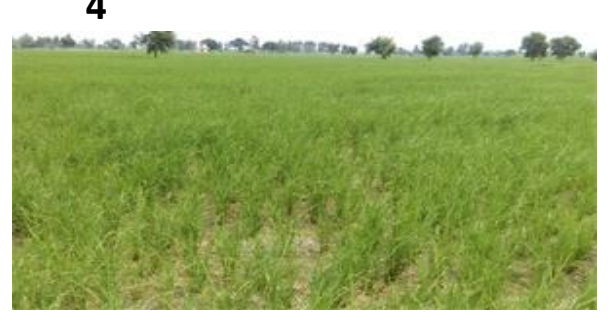


Fig.2 Farming system and integration of livestock with crops

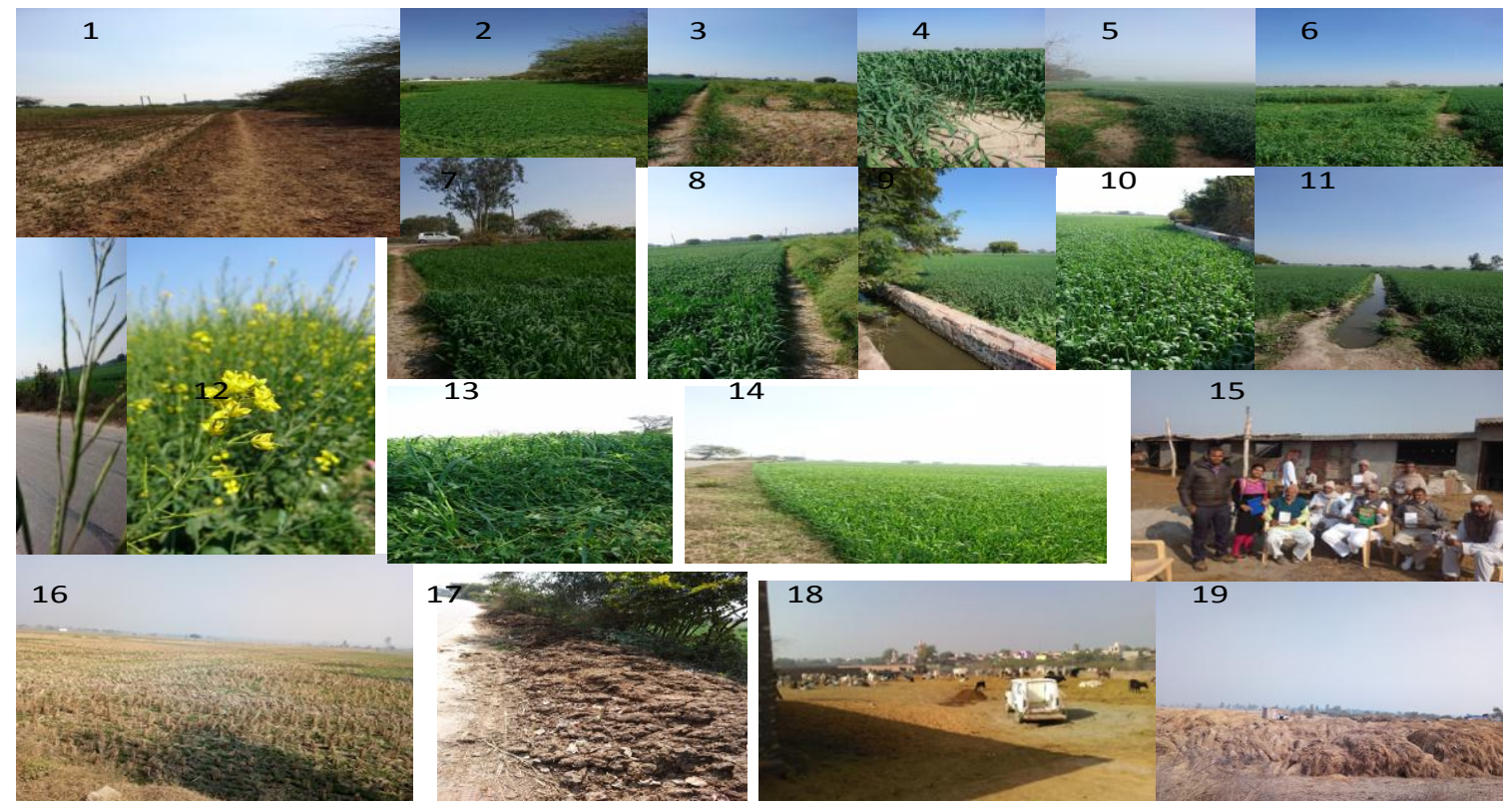

1. Land use change from forest fragments adjacent to agriculture land to agricultural fields (mustard-sorghum rotation system)

2. Legume cover crop and mustard border row

3. Mustard and wheat intercrop

4. Late sown wheat for fodder

5. Wheat as fodder

6. Oat and legume as fodder

7. Wheat at different dates of sowing

8. Mustard as border row

9. Irrigated wheat and irrigation canal

10. Irrigation canal along with road

11. Irrigation system in the field

12. Salinity affected mustard raceme and field

13. Oat and Bersin mix crop for buffaloes and cows

14. Wheat as fodder from low input soil

15. Scientist from various disciplines of Indian Agricultural Research Institute (ICAR), meeting with farmers for problem discussion and dissemination of information and technology

16. No-till wheat after rice in semi-arid areas of Haryana (Bhiwani) for moisture conservation post rainy season

17. Solid dung used for manure at the border of fields need further better management

18. Integration of rice straw in care of stray oxen and cows

19. Rice straw also used along with green fodder for animals

Similarly, Africans have adapted their agricultural practices to a variety of climatic zones. 
Fig.3 Total food grain production of India during four decades

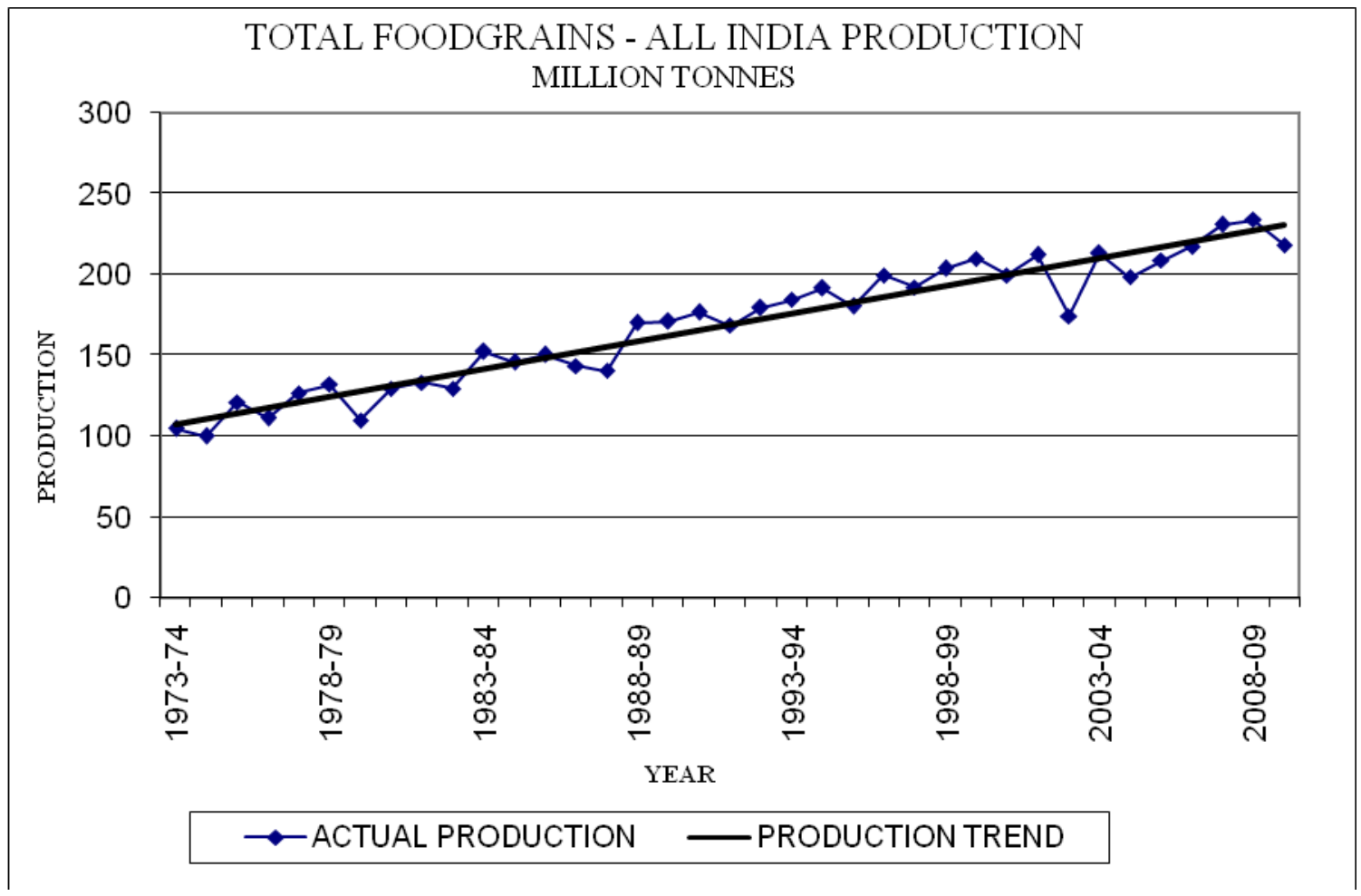

Fig.3a Cotton production during four decades

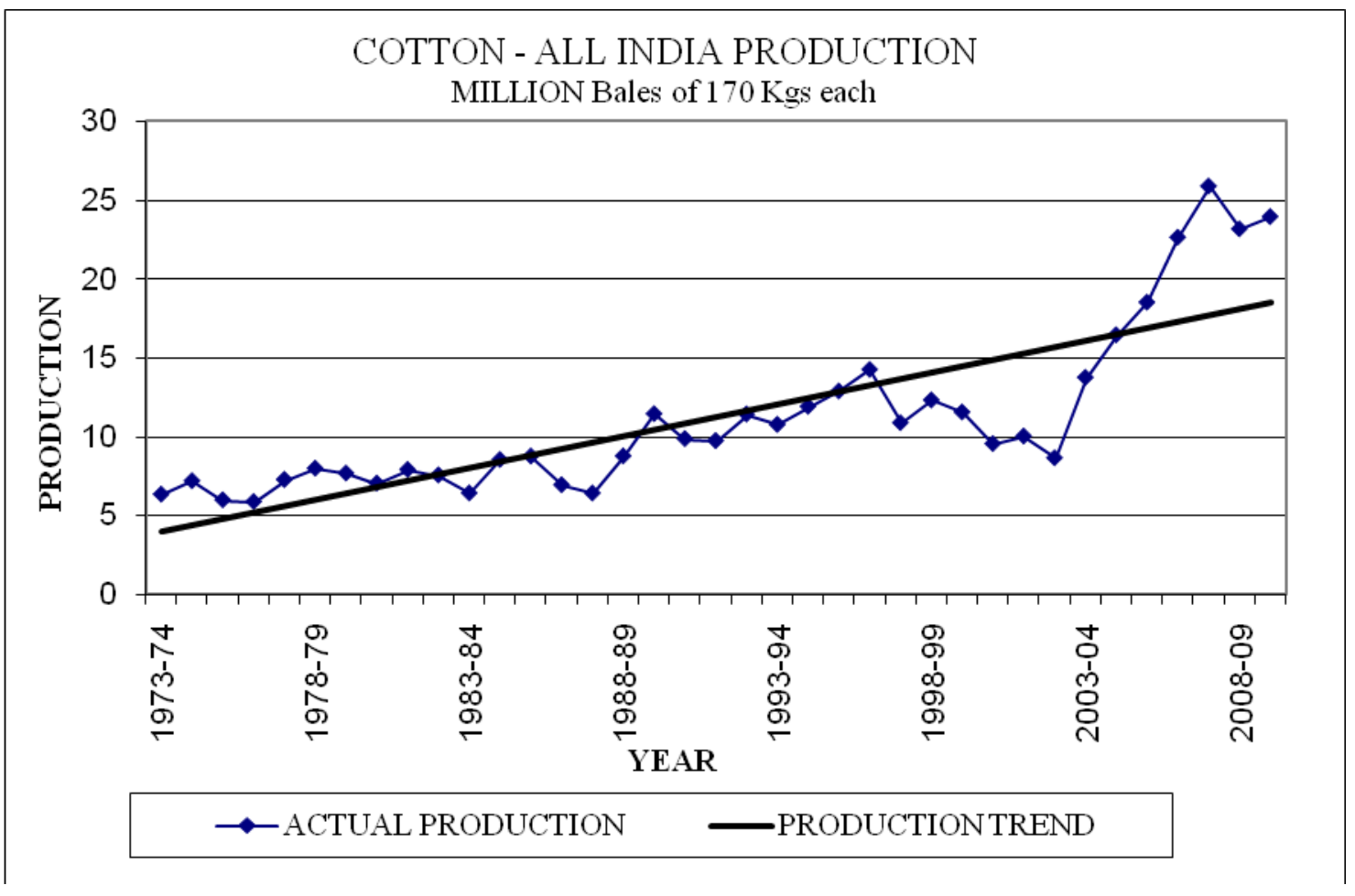


Further, biogas technology can improve social health environment, provide manure as slurry and creates positive synergy between livestock, crop, energy, and economic development. Therefore, rural infrastructure needs to be strengthened through creating post-harvest storage, processing, packaging facilities, marketing/ transporting agricultural products and employment generation. Diverse crops and livestock and smarter seasonal plantings respond differently to abiotic and biotic stresses, prevents losses at the farm; cope better with unpredictable climate changes.

\section{Abbreviations}

AEZ - Agro Eco Zone

C - Carbon

$\mathrm{CH} 4$ - Methane

$\mathrm{CO} 2$ - Carbon dioxide

GCM - General Circulation Model

GHG - Green House Gases

SL - Sustainable Livelihood

SOC - Soil Organic Carbon

NBPGR- National Bureau of Plant Genetic

Resources

NPP - Net Primary Productivity

VAM - Vesicular Arbuscular Mycorrhizae

\section{References}

Akala, V. A. and Lal, R. (2001). Soil organic carbon pools and sequestration rates in reclaimed mine soils in Ohio. Journal Environmental Quality, 30, 2098-2104.

Alexander, J. D. (1969).A color chart for organic matter. Crops and Soils, 21, 157.

Antle, J.M. and Capalbo, S. M. (2010). Adaptation of agricultural and food systems to climate change: an economic and policy perspective. Applied Economic Perspectives and policy, 32, 386-416.

Asner, G. P., Elmore, A. J., Olander, I. P.,
Martin, R. E. and Harris, A. T. (2004). Grazing systems, ecosystems responses, and global change. Annual Review of Environmental Resources, 29, 261-299.

Bagayoko, M., Buerkert, A., Lung, G., Bationo, A. and Römheld, V. (2000). Cereal/legume rotation effects on cereal growth in Sudano-Sahelian West Africa: soil mineral nitrogen, mycorrhizae and nematodes. Plant and Soil, 218, 103-116.

Bank, W. (2011). Climate-Smart Agriculture: Increased Productivity and Food Security, Enhanced Resilience and Reduced Carbon Emissions for Sustainable Development Opportunities and Challenges for a Converging Agenda: Country Examples. Washington, DC: World Bank.

Beauchemin, K. A., McAllister, T.A. and McGinn, S. M. (2009). Dietary mitigation of enteric methane from cattle.CAB Reviews: Perspectives in Agriculture, Veterinary Science, Nutrition and Natural Resources, 4, 118.

Berndes, G., Fredrikson, F. and Borjesson, P. (2004). Cadmium accumulation and Salix-based phytoextraction on arable land in Sweden. Agriculture, Ecosystem and Environment, 103, 207-23.

Betts, R. A., Boucher, O., Collins, M., Cox, P. M., Falloon, P., Gedney, N., Hemming, D. L., Huntingford, C., Jones, C. D., Sexton, D. and Webb, M. (2007a). The projected increase in continental runoff due to plant responses to increasing carbon dioxide. Nature, 448, 10371041.

Bogataj, L. K. and Susnik, A. (2007). Challenges to agrometeorological risk management - regional perspectives: Europe. In: Sivakumar MVK, Motha RP, editors; Managing weather and climate risks in agriculture Springer, 
Berlin, p. 113-124.

Bolin, B., Crutzen, P. J., Vitousek, P. M., Woodmansee, R. G., Goldberg, E. D. and Cook, R. B. (1982). The major biogeochemical cycles and their interactions. Scientific committee on problems of the environment (SCOPE).

Bouman, B. A.M., Humphreys, E., Tuong, T. P. and Barker, R. (2007). Rice and water. Advances in Agronomy, 92, 187237.

Boumer, J., Varallyay, G., Batjes, N. H. (1998). Principal land use changes anticipated in Europe. Agriculture, Ecosystem and Environment, 67, 103119.

Bradley, R. I., Moffat, A. J. and Falloon, P. (2005). Climate change and soil function. Research report to Defra SP0538. UK: Cranfield University.

Branca, G., McCarthy, N., Lipper, L. and Jolejole, M. C. (2011).Climate-Smart Agriculture: A Synthesis of Empirical Evidence of Food Security and Mitigation Benefits from Improved Cropland Management. Mitigation of Climate Change in Agriculture Series no. 3. Rome, Italy: Food and Agriculture Organization of the United Nations (FAO).

Burke, D. (2001). Dairy Waste Anaerobic Digestion Handbook. Environmental Energy Company, Washington.

Carnaval, A. C., Hickerson, M. J., Haddad, C. F. B., Rodrigues, M. T. and Moritz, C. (2009). Stability Predicts Genetic Diversity in the Brazilian Atlantic Forest Hotspot. Science, 323, 785-789.

Chambers, R., Pacey, A., Thrupp, L. A., eds. (1989). Farmer First: Farmer Innovation and Agricultural Research (Intermediate Technology, London).

Charmantier, A., McCleery, R. H., Cole, L. R., Perrins, C., Kruuk, L. E. B. and Sheldon, B. C. (2008). Adaptive phenotypic plasticity in response to climate change in a wild bird population. Science, 320, 800-803.

Chevin, L. M., Lande, R. and Mace, G. M. (2010). Adaptation, Plasticity and Extinction in a Changing Environment: Towards a Predictive Theory. PLoS Biology, 8:e1000357.

Chhabra, A., Manjunath, K.R., Panigrahy, S. and Parihar, J. S. (2013). Greenhouse gas emissions from Indian livestock. Climatic Change, 117, 329-344.

Chopra, R.K. and S. Kumari, 1995. Influence of variable amount of irrigation water and nitrogen fertilizer on growth, yield and water use of grain sorghum. Journal Agronomy Crop Science, 174, 151-161.

Cox, P. M., Betts, R. A., Jones, C. D., Spall, S. A. and Totterdell, I. J., (2000). Acceleration of global warming due to carbon-cycle feedbacks in a coupled climate model. Nature, 408, 184-187.

Delcourt, H.R. and Harris, W.F. (1980). Carbon budget of the southeastern US biota. Analysis of historical change in trend from source to sink. Science, 210 , 321-323.

Doggett, H. (1988). Sorghum second ed., Longman Group UK Limited, London.

Dourmad, J., Rigolot, C. and van der Werf, H. (2008). Emission of Greenhouse Gas: developing management and animal farming systems to assist mitigation. In: Rowlinson, P., Steel, M. and Nefzaoui, A. (Eds.), Livestock and Global Climate Change Conference Proceeding, Cambridge University Press, Tunisia, pp. 36-39.

DSI MSU, (2015). Decision support and informatics. Michigan State University.

Fairhead, J. and Leach, M. (2006). IDS Bulletin, 36, 86-90.

Falloon, P. and Betts, R. (2010). Climate impacts on European agriculture and water management in the context of adaptation and mitigation - the 
importance of an integrated approach. Science of the Total Environment, 408, 5667-5687.

Falloon, P. D., Smith, P. and Powlson, D. (2004). Carbon sequestration in UK arable soils - the case for field margins. Soil Use and Management, 20, 240 247.

FAO (Food and Agriculture Organization). 2003. World Agriculture towards 2015/2030.

FAO (Food and Agriculture Organization). 2010. "ClimateSmart" Agriculture: Policies, Practices and Financing for Food Security, Adaptation and Mitigation. Rome, Italy: FAO.

Fernandez, R.N., Schulze, D. G., Coffin, D. L. and Van Scoyoc, G. E. (1988). Color, organic matter, and pesticide adsorption relationships in a soil landscape. Soil Science Society America Journal, 52, 1023-1026.

Friedlingstein, P., Cox, P., Betts, R. A., Bopp, L., von Bloh, W., Brovkin, V., Doney, S., Eby, M., Fung, I., Govindasamy, I., John, J., Jones, C. D., Joos, F., Kato, T., Kawamiya, M., Knorr, W., Lindsay, K., Matthews, H. D., Raddatz, T., Rayne, P. R., Reick, C., Roeckner, E., Schnitzler, K. G., Schnur, R., Strassmann, K., Thompson, S., Weaver, A. J., Yoshikawa, C. and Zeng, N. (2006). Climate-carbon cycle feedback analysis, results from the C4MIP model intercomparison. Journal Climate, 19, 3337 3353.

Gerber, P. J., Steinfeld, H., Henderson, B., Mottet, A., Opio, C., Dijkman, J., Falcucci, A. and Tempio, G. (2013). Tackling climate change through livestock: a global assessment of emissions and mitigation opportunities. FAO, Rome.

Gomez, B. (2005). Degradation of vegetation and agricultural productivity due to natural disasters and land use strategies to mitigate their impacts on agriculture, rangelands and forestry. In: Sivakumar, M. V. K., Motha, R. P. and Das, H. P., eds. Natural disasters and extreme events in agriculture-impacts and mitigation. Berlin: Springer Verlag, p. 259-76.

Habyarimana, E., Laureti, D., De Ninno, M. and Lorenzoni, C. (2004b). Performances of biomass sorghum (Sorghum bicolor L. Moench) under different water regimes in Mediterranean region. Industrial Crop Production, 20, 23-28.

Hansen L, Hoffman J, Drews C, Mielbrecht E, 2010. Designing climate-smart conservation: Guidance and Case Studies. Conservation Biology, 24:6369.

Harvey, C. (2007). Designing agricultural landscapes for biodiversity conservation. In Farming with Nature: The science and practice of EcoAgriculture. (Eds) Scherr, S. J., McNeely, J. A. Washington, DC: Island Press.

Haussmann, B. I. G., Obilana, A. B., Blum, A., Ayiecho, P. O., Schipprack, W. and Geiger, H. H. (1998). Hybrid performance of sorghum and its relationship to morphological and physiological traits under variable drought stress in Kenya. Plant Breeding, 117, 223-229.

Heath, L. S., Birdsey, R. A., Williams, D. W., Mickler, R. A. and McNulty, S. G. (2002). Methodology for estimating soil carbon for the forest carbon budget model of the United States. Environmental Pollution, 116, 373-380.

Henderson, B. B., Gerber, P. J., Hilinski, T. E., Falcucci, A., Ojima, D. S., Salvatore, M. and Conant, R. T. (2015). Greenhouse gas mitigation potential of the world's grazing lands: modeling soil carbon and nitrogen fluxes of mitigation 
practices. Agriculture, Ecosystem and Environment, 207, 91-100.

Hoffman, A. A. and Sgro, C. M. (2011). Climate change and evolutionary adaptation. Nature, 470, 479-485.

House, L. R. (1985). A guide to sorghum breeding. In: ICRISAT, second eds. Patancheru, A.P., India.

Hulme, M., Jenkins, G. J., Lu, X. Turnpenny, J. R., Mitchell, T. D., Jones, R. G., Lowe, J., Murphy, J. M., Hassell, D., Boorman, P., McDonald, R. and Hill, S. (2002). Climate change scenarios for the United Kingdom: the UKCIPO2 scientific report. Tyndall Centre for Climate Change Research, School of Environmental Sciences. Norwich, UK: University of East Anglia, p. 120.

Huntington, T. (2006). Available water capacity and soil organic matter. Encyclopedia of Soil Science. 2nd edition. Taylor \& Francis.

IFAD (International Fund for Agricultural Development). (2010). Livestock and climate change. Rome.

IFAD. (2011). Rural poverty report. New realities, new challenges: new opportunities for tomorrow's generation. Rome.

IPCC (2007a). Climate Change 2007: The Physical Science Basis. (Eds.) Solomon, S., Qin, D., Manning, M., Chen, Z., Marquis, M., Averyt, K., Tignor, M. M. B. and Miller, H. L., Working Group 1 Contribution to the Fourth Assessment Report of the Intergovernmental Panel on Climate Change (IPCC). Technical Summary and Chapter 10 (Global Climate Projections)

IPCC (Intergovernmental Panel on Climate Change), 2000. Land use, land use change, and forestry. Cambridge University Press, Cambridge.

IPCC (Intergovernmental Panel on Climate Change). (2007b). Climate change 2007: impacts, adaptation and vulnerability. Contribution of Working Group II to the Fourth Assessment Report of the Intergovernmental Panel on Climate Change. Cambridge, UK: Cambridge University Press; p. 976.

IPCC (Intergovernmental Panel on Climate Change). (2008). Climate Change and Water, Technical Paper of the Intergovernmental Panel on Climate Change, IPCC Secretariat, Geneva; p. 210.

IPCC. (2013).Climate change 2013: The physical science basis. In: Stocker, T. F., Qin, D., Plattner, G. K., Tignor, M., Allen, S. K., Boschung, J., Nauel, A., Xia, Y., Bex, V., Midgley, P. M. (Eds), Contribution of Working Group 1 to the Fifth Assessment Report of the Intergovernmental Panel on Climate Change. Cambridge University Press, Cambridge, United Kingdom and New York, NY, USA, p. 1535.

Jazairy, I., Alamgir, M., Pannuccio, T. (1992). The State of World Rural Poverty: An Inquiry into its Causes and Consequences (New York Univ Press, New York).

Jenkinson, D. S., Adams, D. E. and Wild, A. (1991). Model estimates of $\mathrm{CO}_{2}$ emissions from soil in response to global warming. Nature, 351, 304-306.

Jones, C. D., McConnell, C., Coleman, K. W., Cox, P. and Falloon, P. D., Jenkinson, D. S. and Powlson, D. (2005). Global climate change and soil carbon stocks; predictions from two contrasting models for the turnover of organic carbon in soil. Global Change Biology, 11, 154166.

Jones, P. D., Lister, D. H., Jaggard, K. W., Pidgeon, J. D. (2003). Future climate impact on the productivity of sugar beet (Beta vulgaris L.) in Europe. Climatic Change, 58, 93-108.

Kauppi, P. E., Mielikäuainen, K. and Kuusela, K. (1992). Biomass and 
carbon budget of European forests, 1971 to 1990. Science, 256, 70-74.

Kaye, N. M., Mason, S. C., Galusha, T. D. and Mamo, M. (2007). Nodulating and non-nodulating soybean rotation influence on soil nitrate-nitrogen and water, and sorghum yield. Agronomy Journal, 99, 599-606.

Kiers, E. T., Palmer, T. M., Ives, A. R., Bruno, J. F. and Bronstein, J. L. (2010). Mutualisms in a changing world: an evolutionary perspective. Ecology Letters, 13, 1459-1474.

Kok, C. J., Coenen, G. C.M. and de Heij, A. (1994). The effect of fiber hemp (Cannabis sativa L.) on selected soilborne pathogens. Journal of International Hemp Association, 1, 6-9.

Lal, R. (2005). Forest soils and carbon sequestration. Forest Ecology and Management, 220, 242-258.

LEAD (Livestock Environment and Development). (2014). Livestock role in deforestation. Food and Agriculture Organization of the United Nations (FAO).

Lemus, R. and Lal, R. (2005). Bioenergy crops and carbon sequestration. Critical Reviews in Plant Sciences, 24, 1-21.

Montanarella, L. (2007). Trends in land degradation in Europe. In: Sivakumar, M. V. K. and Ndegwa, N., editors. Climate and land degradation. Germany: Springer-Heidelberg, 83-104.

Mosier, A., Wassmann, R., Verchot, L., King, J. and Palm, C. (2004). Methane and nitrogen oxide fluxes in tropical agricultural soils: sources, sinks and mechanisms. Environment, Development and Sustainability, 6, 1149.

Motha, R. P. (2007). Development of an agricultural weather policy. Agriculture and Forest Meteorology, 142, 303-313.

Parmesan, C., (2006). Ecological and evolutionary responses to recent climate change. Ecology Evolution, 37, 637669.

Porter, J. R. and Semenov, M. A. (2005). Crop responses to climatic variation. Philosophical Transactions of Royal Society B, 360, 2021-2035.

Post, D. F., Fimbres, A., Matthias, A. D., Sano, E. E., Accioly, L., Batchily, A. K. and Ferreira, L. G. (2000). Predicting soil albedo from soil color and spectral reflectance data. Soil Science Society America Journal, 64, 1027-1034.

Powlson, D. S., Christian, D. G., Falloon, P. and Smith, P. (2001). Biofuel crops: their potential contribution to decreased fossil carbon emissions and additional environmental benefits. Aspects Applied Biology, 65, 289-294.

Rafferty, N. E. and Ives, A. R. (2010). Effects of experimental shifts in flowering phenology on plant-pollinator interactions. Ecology Letters, 14, 6974.

Rattunde, H. F. W., Weltzien, E., Diallo, B., Diallo, A. G., Sidibe, M., Touré, A. O., Rathore, A., Das, R. R., Leiser, W. L. and Touré, A. (2013). Yield of photoperiod-sensitive sorghum hybrids based on guinea-race germplasm under farmers' field conditions in Mali. Crop Science, 53, 2454-2461.

Salamin, N., Wüest, R. O., Lavergne, S., Thuiller, W. and Pearman, P. B. (2010). Assessing rapid evolution in a changing environment. Trends in Ecology and Evolution, 25, 692-698.

Santos, F. D., Forbes, K. and Moita, R. editors. (2002). Climate change in Portugal: scenarios, impacts and adaptation measures. SIAM project report, Gradiva, Lisbon, Portugal, p. 456.

Santosh Kumari (2010). Cellular changes and their relationship to morphology, abscisic acid accumulation and yield in wheat (Triticum aestivum) cultivars 
under water stress. American Journal of Plant Physiology, 5, 257-277.

Santosh Kumari (2011). Influence of Drip Irrigation and Mulch on Leaf Area Maximization, Water Use Efficiency and Yield of Potato (Solanum tuberosum L.). Journal of Agricultural Science Vol. 4(1): 71-80.

Santosh Kumari (2013). Lutein, Anthocyanin and Xanthophyll Cycle Components in Wheat (Triticum aestivum) Flag Leaves Under high Light and high-Temperature Conditions. Indian Journal of Applied Research, Indian Journal of Applied Research, 3(4), 1-3.

Santosh Kumari (2017). Chickpea (Cicer arietinum) growth and productivity changes through acquisition of limiting nutrients (Nitrogen-N and PhosphorusP) by Rhizobium and microphos. International Journal of Current Microbiology and Applied Sciences, 6(10), 2381-2386.

Santosh Kumari (2017). Effect of kinetin (6FAP) and cycocel (CCC) on growth, metabolism and cellular organelles in pearl millet (Pennisetum glaucum L.) under water stress. International Journal of Current Microbiology and Applied Sciences, 6(8), 2711-2719.

Santosh Kumari (2017). Effects of nitrogen levels on anatomy, growth, and chlorophyll content in sunflower (Helianthus annuus L.) leaves. Journal of Agricultural Science, 9(8), 208-219.

Santosh Kumari (2017a). Effect of growth retardant (CCC) and growth promoter (6-FAP) on seedling growth and chlorophyll content of Coleoptile leaves in pearl millet (Pennisetum glaucum L.) under moisture stress. International Journal of Current Microbiology and Applied Sciences, 6(9), 2522-2529.

Scherr, S. J. and Sthapit, S. (2009). Mitigating Climate Change through Food and Land Use. World watch Report No. 179.
Washington, DC: World Watch Institute.

Schulze DG, Nagel JL, Van Scoyoc GE, Henderson TL, Baumgardner MF, 1993. Significance of organic matter in determining soil colors. In: Bigham, J. M., Ciolkosz, E. J., (Eds.) Soil color, vol 31. Madison, WI: SSSA Special Publication; p. 71-90. SSSA.

Shvidenko, A., Nilsson, S. and Stocks, B. J. (2002). Dynamics of Russian forests and the carbon budget in 1961-1998: an assessment based on long-term forest inventory data. Climatic Change, 55, 537.

Steinfeld, H., Gerber, P., Wassenaar, T., Castel, V., Rosales, M. and Haan, C. (2006). Livestock's long shadow; Environmental Issues and Options. FAO, Rome.

Sthapit, B., Padulosi, S. and Mal, B. (2010). Role of on- farm/In situ conservation and underutilized crops in the wake of climate change. Indian Journal Plant Genetic Resources, 23, 145-156.

Stroosnijder, L. (2007). Rainfall and land degradation. In: Sivakumar, M. V. K. and Ndegwa, N. (Eds.) Climate and land degradation. Germany: SpringerHeidelberg, p. 167-95.

Thornton, P. K. and Herrero, M. (2010b). The Inter-linkages between rapid growth in livestock production, climate change, and the impacts on water resources, land use, and deforestation. World Bank Policy Research Working Paper, WPS 5178. World Bank, Washington, DC.

Tolbert, V. R., Thornton, F. C., Joslin, J. D., Bock, B. R., Bandaranayake, W., Houston, A. E., Tyler, D. D., Mays, D. A., Green, T. H. and Pettry, D. E. (2000). Increasing belowground carbon sequestration with conversion of agricultural lands to production of bioenergy crops. New Zealand Journal Forestry Science, 30, 138-149. 
UNEP (United Nations Environment Programme). (2011). Promoting climate resilience in the rice sector through pilot investments in Alaotra-Mangoro region. Climate Change Adaptation Proposal to Adaptation Fund. Washington, DC Adaptation Fund.

Varvel, G. E. and Wilhelm, W. W. (2003). Soybean nitrogen contribution to corn and sorghum in western Corn Belt rotations. Agronomy Journal, 95, 1220 1225.

Visser, M. E. (2008). Keeping up with a warming world; assessing the rate of adaptation to climate change. Proceedings of the Royal Society B-Biological Sciences, 275,
649-659.

Wassenaar, T., Gerber, P., Verburg, P. H., Rosales, M., Ibrahim, M. and Steinfeld, H. (2007). Projecting land use changes in the Neotropics: The geography of pasture expansion into forest. Global Environmental Change, 17, 86-104.

Webb, J., Anthony, S., Brown, L., LyonsVisser, H., Ross, C., Cottril, B., Johnson, D. and Scholefield, D. (2005). The impact of increasing the length of the cattle grazing season on emissions of ammonia and nitrous oxide and on nitrate leaching in England and Wales. Agriculture, Ecosystems and Environment, 105, 307-321.

\section{How to cite this article:}

Santosh Kumari, Tej Pal Singh and Shiv Prasad. 2019. Climate Smart Agriculture and Climate Change. Int.J.Curr.Microbiol.App.Sci. 8(03): 1112-1137. doi: https://doi.org/10.20546/ijcmas.2019.803.134 